\title{
(FTFs) Foreign Terrorist Fighters in Indonesia
}

\author{
Masmuhah \\ S. Sos (Bachelor of Social and Political Science), Master Candidate in University of Indonesia, Indonesia, \\ masmuhahoecha@hotmail.com \\ Yon Machmudi, Ph.D \\ Head of Department of Middle East Studies University of Indonesia \\ yonmachmudi@yahoo.com
}

\begin{abstract}
Over the past four years, ISIS has rapidly become the most dangerous of transnational influences on jihadism in Southeast Asia. It has recruited and mobilized hundreds of Southeast Asian fighters for military and other services in Syria and Iraq and has drawn pledges of loyalty from several thousand jihadists in the region. This research explains the motivation of foreign terrorist fighters Indonesia joining ISIS (Islamic State of Iraq and Syria). There are three factors which influenced most youth people becoming FTFs in Syria: ideology, financial incentive and material rewards, and internet. To decrease the number of Indonesian FTFs to go to Syria, this study recommends the government to Reinforced Check at External Border; Reformulate Combating Terrorism Criminal Act; socialize deradicalization and mismanagement, and strengthening economic empowerment. This study is a qualitative research and using descriptive analysis method.
\end{abstract}

Keywords - Foreign terrorist fighters, terrorism, ISIS.

\section{INTRODUCTION}

The rise of extremist groups in the Syrian civil war and the post-invasion chaos of Iraq remains essentially a local and regional phenomenon, with the majority of recruits coming from Arab states. Tunisians, Saudis, and Jordanians continue to Asia, especially Southeast Asia [1].

The official counts for Southeast Asians fighting in Syria may be on the high side. Since July 2014, the Islamic State has posted propaganda and recruitment videos aimed at persuading Indonesians and Malaysians to perform hijrah to Syria with their families. One video showed Malay-speaking children training with weapons in Islamic State-held territory while two Malaysians were featured in another Islamic State video of the beheading of a Syrian man [2].

The main problem of the existence of the FTF is not only the ability of the government in protecting and preventing citizens from being contaminated with wrong values of jihad and then fighting abroad, but also, the real concern is if the WNI who became the FTF who return to their country as a combatant.

\section{RESEARCH QUESTION}

The research question is What is the motivation of Foreign Terrorist Fighter Indonesia to join Islamic State of Iraq and Syria. This research aims to understand why some individuals decide to travel to an armed conflict state (in this case Syria) for joining a transnational terrorist organization, like ISIS; to enhance understanding of why some of these individuals decide to return to their country of residence or nationality after travelling to a conflict zone (Syria) and joining a transnational terrorist group before fully achieving their goals [3].

\section{THEORETICAL FRAMEWORK}

UN Security Resolution 2178 defines foreign terrorist fighters as "individual who travel to a State other than their State of residence or nationality for the perpetration, planning or preparation of or participation in, terrorist acts or the providing or the receiving of terrorist training, including in connection with armed conflict. According to the Security Council, terrorist organizations such as Al-Qaeda, the Islamic State of Iraq also knownas Da'esh and associated groups have attracted over 30.000 FTFs from over 100 Member States. In both developed and developing countries, significant numbers of young people are considering traveling to areas where their securitywould be at risk. The departure of so many young people to conflict zones has a profoundly destabilizing effect on their communities and above all, on their families. To attract individuals to its cause, ISIS exploits socioeconomic grievances and feelings of alienation, marginalization, discrimination, or victimization by host factors, including lack of opportunities, lack of good governance injustice, and feeling injustice [4].

By some estimation, over 25,000 foreigners had gone to fight in Syria between the start of the civil war in 2011 to September 2016 (4). The number is far lower compared to conflicts such as the Afghan war (1979-1989), the war in Bosnia (1992-1995), or the war in Iraq (2003-2006). Not only the number of FTFs that is far larger and the rate of flow way faster than in these previous wars, but also the range of the countries from which they come. In May 2015, the United Nations Analytical Support and Sanctions Monitoring Team pursuant to resolutions 1526 (2004) and 2253 (2015) concerning ISIL (Da'esh), Al-Qaida and the Taliban and associated individuals and entities reported that FTFs had gone to Syria from over 100 Member States, including some 
that had never experienced problems with groups associated with Al-Qaida [3].

Terrorism itself is one of extraordinary crime. The use of violence aiming to create fear in a wider audience to prevent various parties from doing something, or, on the contrary, to coerce them into a certain behaviour, is as old as mankind. Such use of violence has served states and various regimes over a long period [5]. Terrorist by the state(or non-state actors) involves deliberate coercion and violence directed at some victim, with the intention of inducing extreme fear in some targets observers who identify with that victim in such a way that they perceive themselves as potential future victims. In this way, they are forced to consider altering their behavior in some manner desire by the actor. The 'academic consensus definition' of terrorism is a case in point:

"Terrorism is an anxiety-inspiring method of repeated violent action, employed by (semi-) clandestine individual, group or state actors, for idiosyncratic, criminal or political reasons, a whereby-in contrast to assassination - the direct targets of violence are not the main targets. The immediate human victims of violence are chosen randomly (targets of opportunity) or selectively (representative or sym- bolic targets) from a target population, and serve as message genera- tors. Threat and violence based communication processes between terrorist (organization), (imperilled) victims, and main targets are used to manipulate the main target (audience(s)), turning it into a target of the use of violence with the aim of creating fear in a wider audience in order to prevent various parties from doing something, or, on the contrary, to coerce them into a certain behaviour, is as old as mankind. Such use of violence has served states and various regimes over a long period [6].

\section{FOREIGN FIGHTER NUMBER}

The first Indonesian fighters to go to Syria were already in the Middle East on student visas, often sponsored by radical groups at home that also introduced them to the Arab mujahidin networks that originally funneled fighters into Afghanistan. Theirposts on social media spoke of "five-star jihad" in Syria and when tweets of the first Indonesian "martyrs" to die fighting the Assad regime surfaced, a steady stream of known extremists and those who had previously fought with the al-Qaeda affiliate inSoutheast Asia, Jemaah Islamiyah, began heading to Syria. When Abu Bakr alBaghdadi declared his caliphate, the extremist community began recruiting in earnest, transforming support for local jihadi struggles into support for Islamic State, egged on by a radical preacher admired for translating Islamic State literature into Indonesian from prison [1].

In June 2015, there were 202 cases of Indonesian fighters in the Middle East, but officials admit the real figure could be dozens higher than this. The Institute of Policy and Conflict (IPAC), the Jakarta-based non-governmental research center that is doing the most authoritative analysis of Indonesian terrorism issues, believes that between 250 and 300 local jihadists may be fighting with ISIS. The Indonesian government came up with an official count of 800 Indonesians as FTFs in November 2015 [1].

After the IS claimed responsibility for the attack in Jakarta in January 2016 the risk posed by radical Islam came to surface. The precise level of support for ISIS is difficult to ascertain. Official figures on the number of fighters and actively supportive partisans of ISIS vary greatly, and some government spokespeople appear inclined to disseminate inflated statistics to galvanize public reactions. The threat of returnees of FTFsbecomes increasingly prevalent when The chief of police suspects in a June stabbing murder of a police officer in North Sumatra had been to Syria in 2013. Ms. Jonesterrorist analyst fromInstitute for Policy Analysis of Conflict said monitoring of returns was not always effective, but it was a matter of police resources.

A Recent report said that out of the 4957 FTFs arrested in Turkey. Surprisingly, Indonesia is number two on the worldwide list of foreign Islamic State jihadist arrested in Turkey with 435 arrests after Russia in the top list with 804 people. Another also points out that many of the Indonesians arrested so far in Turkey include the whole family and a large number of women and children [7]. The government announced that 152Indonesians, including women and children, were apparently deported from Turkey before they could cross the border into Syria between January and June 2017.

\section{MOTIVATION AND DRIVER TO SUPPORT}

For Indonesians, the attraction of joining ISIS is different from previous episodes of transnational jihadism. For Indonesians involved in jihad in Afghanistan in the mid-1980s and Mindanao in the mid-1990s, there was both push and pull factors influencing them. There is a lack of solid empirical evidence and consensus on what motivates an individual to leave Indonesia to join a terrorist organization in a foreign country.

A growing body of research, some of which is discussed above, believes that secular issues, particularly the hope of economic and financial reward now play a larger role than in the past. Other studies focus more on the role of ideology. A third group stresses the role of political factors, particularly the violation of human rights and the lack of democratic forums as key push-factors [3].

\section{A.. The role of ideology}

Marc Sageman said, 'ideology, including global neojihadi ideology, is an important part of any explanation of political violence. However, we still do not understand how' The survey conduct by UN Counter Terrorism-Center claimed that almost $40 \%$ of the sample (43 respondents) stated that their motivation to go to Syria arose from an obligation to 
defend their fellow Sunnis from the Syrian Government and its allies by force. It confirms that much Muslim youths, regardless of where they come from, perceive the conflict in Syria in the community more than in religious terms [3]. Solidarity with other fellow Muslims abroad (in Syria mostly, and especially during the early stages of FTFs travel), the fight against the Syrian Government, the desire to live in a territory ruled by Islamic law, alienation and social exclusion felt in Europe, as well as the desire to conduct jihad. For some, the search for excitement and adventure play a role, as does peer pressure and the prospects of life in the caliphate ISIS.

Another consideration is ISIS has developed an aura of power and momentum that brings credibility. ISIS has been able to repeatedly defeat the Western-backed Iraqi, Kurdish and Syrian forces in a way that no jihadist movement has succeeded in doing since the mujahidin war against the Soviet Union in Afghanistan.

\section{B. The role of financial incentive and material rewards}

The influence of material reward as an element of FTFs motivation deserves some attention, given evidence of its existence in other studies and the lack of consensus over its real weight. It is likely that very few FTFs would openly admit that material gain was a motivator behind their decision to go to Syria. Some of them perhaps sought to play a larger role in the establishment of the Islamic State as paid bureaucrats and administrators rather than as fighters. Indeed, after the declaration of the Caliphate in June 2014, ISIS focused on building a state as much as on conquering territory, and therefore needed engineers, doctors, teachers, judges, imams, technicians, and administrators of all types.These opportunities are likely to have attracted more experienced FTFs, even though the majority of the youth in our sample did not seem to have bought into the idea of an Islamic State.

In fact, ISIS is the wealthiest terrorist group in the world; its annual turnover amounts to around $\$ 2$ billion- $\$ 3$ billion. Their main funding source is from oil trade, a collection of protection and taxes bank robberies and looting. They have financial ability to recruit new members from around the world. When the FTF hijrah they promised will get the wealth, security and protection. Yusuf Adirama ex-jihadist said,"I've heard that every FTFs is guaranteed a salary of 100 million to 150 million rupiahs per month."

\section{The role of Internet}

ISIS is a very clever movement utilizing Internet media as a propaganda medium. ISIS is one of the terrorist movements capable of utilizing social media as a propaganda media as well as membership recurrence. For the context in Indonesia until March 2015 the tweet of ISIS from Indonesia contributed $20 \%$ of the total world tweet (112.075 / world 21.722 / Indonesia). The first video appeared on July 31 on Youtube inviting Indonesians to join ISIS. The propaganda continued with other videos containing ISIS threats against TNI Jend Muldoko, Kapolri, Baser and the whole Indonesian nation, will slaughter the five people who disagree with them and there are other examples of ISIS propaganda patterns in Indonesia [8].

Social media is important in promoting ISIS beliefs and in radicalizing recruits but, it is not, in Indonesia, the sole or even critical conduit for entering the Islamic State. In Malaysia, where jihadists are organizationally weak, the Internet appears to play a greater role.

The decision to go to Syria is the result of a mix of factors that form a complex set of motivations. What is certain is that social networks often seem to play a key role as a mechanism channeling the energies of youth towards departure for Syria. This process is carried out in real life through face-to-face encounters rather than through the Internet. What is equally important is the role and identity of the recruiters, who are not necessarily members of armed groups. They are more likely to be sympathizers who are well known, well connected and even well established in their communities, according to most interviews in this survey. The individual determination (selfmotivation) to leave home more often than not results from the influence of these social networks, coupled with poor prospects for political, social and economic advancement.

\section{RECRUITMENT}

Recruits to ISIS come from a diverse range of age, educational, vocational and socio-economic backgrounds. Teenagers have joined ISIS, as have jihadists in their 50s. Some are junior or secondary school dropouts; others have graduate qualifications. Some are itinerant workers, but others have successful professional careers as doctors, teachers, engineers and public servants. In short, there is no single profile for ISIS recruits.

\section{A. Youth FTFs}

The transition period of identity crisis among youths is likely to experience what Quintan Wiktorowicz (2005) calls cognitive opening, a micro-sociological process that draws them closer to acceptance of a more radical new idea. It is these reasons that make them particularly vulnerable to the influence and call for violence and terrorism. Meanwhile, terrorist groups are aware of the psychological problems of the young generation. Terrorist groups are mostly those who always feel dissatisfied, irritable and frustrated both with social conditions and government. They have also provided what they need regarding the doctrine of justification, solutions and strategies for change, and a sense of ownership. Terrorist groups also provide environments, facilities, and equipment for youth who want their valor and launch their violent agendas.

It is very alarming to see facts that show youth closeness to the culture of violence. The presence of the Islamic State of Iraq and Syria (ISIS) is a frightening new specter for the 
young generation with various provocations, propaganda and lucrative violence. Since its emergence stamped the nation's security situation, ISIS has at least been able to thrill the passion of young people to get involved in the violent political movement in Syria. Some examples that can be mentioned is Wildan who died in Iraq when joining ISIS. Wildan is a student at Pondok Al Islam in Tenggulun, Lamongan, which is managed by the Amrozi family convicted in the 2002 Bali bombing. In his young age, this Lamongan origin chose to end his life in a land full of conflict.

Not only among the men, Asyahnaz Yasmin (25 years), including one of 16 Indonesian citizens who was arrested by the Turkish government. This Bandung girl after being returned to Indonesia, she was rejected by her family and local regent. Ministry of Social RI also accommodated back in the home protection and trauma center. And of course, there are many other stories. These facts show how the vulnerability among the younger generation of the influence of teaching as well as the invitations propagated by radical groups both directly and through online media that became very popular lately. For this reason, efforts to fortify the younger generation from the influence of teaching and the attraction to violence are a common task.

There are three important social institutions to play in protecting the younger generation. First Education, through the role of educational institutions, teachers, and curriculum in strengthening national insight, moderation, and tolerance to the younger generation. Secondly, the Family, through the role of parents in instilling love and affection to the younger generation and making the family as a unit of consultation and discussion. Third, the community: through the role of community leaders in the community environment in creating a conducive space for the creation of a culture of peace among the younger generation.

\section{RECOMMENDATION}

\section{A. Reinforced Check at External Borders}

The government should strictly control all issuing passports and visas, create connection database between the National Agency for Combating Terrorism, national police and immigration.

\section{B. Reformulate Combating Terrorism Criminal Act.}

Stakeholder must reformulate and consider the sanctions of deprivation of citizenship as an additional criminal sanction in article $12 \mathrm{~B}$ of paragraph 6 in the Act. The problem is what can be threatened with the sanction of deprivation of citizens and who is referred as an authorized official to impose such sanctions. It should be considered as the consequences, for example, the possibility of the suspected being stateless.

\section{Deradicalization and Disengagement}

The state is obliged to protect every citizen as mandated by the 1945 constitution of the Republic of Indonesia. The results of some research pointed out that counter-terrorism is a prevention and control effort against terrorism consisting of deradicalization, disengagement, andincapacitation. It is expected that radicalization and disengagement are applied together as a complementary program between social approach (disengagement) and psychological approach (deradicalization).

\section{Economic Empowerment}

This activity is directed to create an entrepreneurial spirit among Muslim Indonesian and the development of shariah economy with medium and long-term goals to fortify the ummah from the dominance of global capitalism. This activity is simultaneous to practice the spirit of pluralism in the economic field between the rich and the poor, a synergy between those who are economically strong and the weak for the sake of mutual benefit [9].

\section{CONCLUSION}

This study concludes that there are some factors and motivations driving Indonesian citizens becoming FTFs under ISIS. First, the role of ideology. Many youth Muslim who is going to Syria perceive the conflict in Syria in the community more than in religious terms. Their motivation to go to Syria arose from an obligation to defend their fellow Sunnis from the Syrian Government and its allies by force. Second, the role of financial incentive and material rewards. Many of them are tempted by the promise of great material reward and a guarantee ofa better live Third, the role of the internet in which social media is important in promoting ISIS beliefs and in radicalizing recruits. 


\section{References}

[1] Funston, Greg Fealey and John. "Indonesian and Malaysian Support for Islamic State (Final Report) ." United States Agency for International Development. 6 January 2016. United States Agency for International Development. (http://www.globalsecurity.org/military/library/report/2016/PBA AD863.pdf) (accessed on August 10, 2017).

[2] Transcript of Keynote Speech by Singapore Prime Minister Lee Hsien Loong at the Shangri-LaDialogue on 29 May 2015, available on ( http://www.pmo.gov.sg/mediacentre/transcriptkeynote-speechprime-minister-lee-hsien-loong-shangri-ladialogue-29-may-2015)

[3] el-Said, Professor Hamed. "Enhancing the Understanding of the Foreign Terrorist Fighters Phenomenon in Syria." un.org.July 2017.(http://www.un.org/en/counterterrorism/assets/img/Report _Final_20170727.pdf) (accessed on August 20, 2017).

[4] "Foreign terrorist fighters." Security Council Counter-Terrorism Committee. t.thn.(https://www.un.org/sc/ctc/focus-areas/foreignterrorist-fighters/) (accessed on August 20, 2017).
[5] http://www.ksk.edu.ee/wpcontent/uploads/2011/03/KVUOA_Toimetised_12-Männik.pdf

[6] United Nations Office on Drugs and Crime. Definitions of Terrorism.

2007.<http://www.unodc.org/unodc/terrorism_definitions.html>, (accessed 15 August2017).

[7] Wockner, Cindy. Indonesia in number two on the worldwide list of foreign Islamic State jihadists arrested in Turkey. News.com.au. July 2017. (http://www.news.com.au/world/asia/indonesia-in-number-twoon-worldwide-list-of-foreign-islamic-state-jihadists-arrested-inturkey/news-story/75f00d11a254935fb49a9925c379c25e) (accessed on August 2017)

[8] BNPT (Badan Nasional Penanggulangan Terror), 2016 Strategi Menghadapi Paham Radikalisme-ISIS

[9] NU Online 2016, (The role of NU Combating radicalism) Peran NU dalam menangkal radikalisme accessed from http://www.nu.or.id/post/read/58396/peran-nu-dalammenangkal-radikalisme on June 2201 